\title{
Evaluation of Anatomical Variations on Paranasal Sinus CT
}

\author{
Demet Yazıcı, MD \\ Adana City Training and Research Hospital, ENT Department, Adana - Turkey
}

\begin{abstract}
Objective: The purpose of this study was to analyze and assess the frequency of anatomical variants of the paranasal sinuses as detected by multidetector computed tomography (MDCT) scanning.

Methods: 225 patients (122 males, 103 females) in total, with a median age of 28 (range: 15-77) years were included in this retrospective study. Paranasal computed tomography was conducted in all cases. The scans were reviewed to discover the incidence of nasal septal deviation (NSD), variations of the nasal turbinates, ethmoidal air cells, paranasal sinus pneumatization, accessory pneumatization of the paranasal complex, variations in the sphenoid sinus-related structures and the optic nerve and Vidian canal classification type.
\end{abstract}

Results: NSD was present in 124 (55.1\%) of individuals, superior concha pneumatization in 30 (13.3\%), middle concha pneumatization in $100(44.4 \%)$, Agger nasi cells (ANC) in 192 (85.3\%), Haller cells in 47 (20.9\%), Onodi cells in 44 (19.6\%), maxillary sinus hypoplasia in 6 (2.6\%), frontal sinus hypoplasia in 29 (12.9\%), frontal sinus aplasia in $7(3.1 \%)$, sphenoid sinus hypoplasia in $7(3.1 \%)$, uncinate process pneumatization in $12(5.3 \%)$, anterior clinoid process (ACP) pneumatization in $60(26.7 \%)$ and pterygoid process (PP) pneumatization in 75 (33.3\%). Optic nerve Type 1 was found in $122(54.2 \%)$ individuals, Type 2 in 29 (12.9\%), Type 3 in $36(16 \%)$ and Type 4 in 38 $(16.9 \%)$. Vidian canal Type 1 was observed in 37 (16.4\%), Type 2 in 95 (42.2\%) and Type 3 in 93 (41.3\%) individuals.

Conclusion: The analysis of paranasal CT is crucial in the diagnosis of miscellaneous diseases of the paranasal sinuses. Anatomical variations in the sinuses are highly prevalent, so otorhinolaryngologists should be aware of these variations to allow them to reach precise diagnoses and avoid surgical complications.

Key words: Paranasal sinuses, nasal septum, nasal surgery, multidetector computed tomography, anatomic variation

\section{Introduction}

Paranasal sinus variations are frequent, miscellaneous and are thought to be a major leading cause of chronic rhinosinusitis and various sinonasal diseases, such as retention cysts. Analysis of these variations in paranasal computed tomography (CT) is essential for preoperative assessment prior to functional endoscopic sinus surgery, in order to avoid complications.

In this study, we analyzed the frequency of anatomical variations in paranasal CTs of patients attending our

ENT clinic. The paranasal CTs were evaluated in terms of sex, age, the direction of the nasal septal deviation (NSD), variations of the nasal turbinates, ethmoidal air cells, pneumatization patterns of the frontal, maxillary and sphenoid sinuses, and optic nerve and Vidian canal types. The results obtained were then compared with the current literature on this topic.

\section{Materials And Methods:}

225 patients in total (122 males, 103 females) who un-

Correspondence: Demet Yazıc1, MD

Adana City Training and Research Hospital, ENT Department, Adana - Turkey e-mail: drdemetyazici@gmail.com

Received: 1st, August, 2018; Accepted: 12th, November, 2018
Online available at: www.entupdates.org 品婹品 
derwent multidetector computed tomography (MDCT) between April 2017 and April 2018 were enrolled in this retrospective study. Cases with previous nasal septal or endoscopic sinus surgery, a history of facial trauma, sinonasal tumors, sinonasal polyposis or sinusitis were, however, excluded from the study. An approval was obtained from our institution's ethics committee (No:195/2018)

All the paranasal CT results collected were assessed by the author, a senior otorhinolaryngology consultant. The axial and coronal scans of the paranasal CT were retrospectively reviewed for the presence of NSD, middle and upper concha pneumatization, agger nasi cells (ANC), Haller cell and Onodi cell, hypoplasia or aplasia of the frontal sinus, maxillary sinus and sphenoid sinus, pneumatization of the anterior clinoid process (ACP), pterygoid process $(\mathrm{PP})$, pneumatization of the crista galli, optic nerve type (following the classification scheme of Delano et al.) and Vidian canal type (following the classification scheme of Lee et al. $)^{[1,2]}$

The Paranasal CT scans were performed by using a 128-slice dual-source CT (Philips Ingenuity Core, Netherlands). The imaging parameters were KvP: 120, mAs: 10, pitch: 0.399, helical thickness: $1 \mathrm{~mm}$ for coronal images, $0.67 \mathrm{~mm}$ for axial images, rotation time: $0.4 \mathrm{~s}$.

The statistical package SPSS (version 20.0) was used for the statistical evaluation. Chi-squared test and Fisher's exact test were used to determine any differences between groups. A value of $\mathrm{p}<0.05$ was defined as constituting statistical significance.

\section{Results:}

The paranasal CT scans of 225 cases fulfilled the criteria for inclusion in the study. The sex distribution, median age, prevalence of anatomical variations and types of optic nerve and Vidian canal on paranasal CT scan is shown in Table 1. There were 122 (54.2\%) male patients and 103 $(45.8 \%)$ female patients with a median age of $28(15-77)$ years. The median age of the male patients was $29(15-$ 77) years whilst that of the female patients was 26 (1661) years. NSD was present in $124(55.1 \%)$ patients, 84 $(37.3 \%)$ patients had right-sided deviation, and 40 (17.8\%) patients had left-sided nasal deviation. The other paranasal sinus variations were as follows: middle concha pneumatization in $100(44.4 \%)$; superior concha pneumatization in $30(13.3 \%)$ patients; ANC in $192(85.3 \%)$; Haller cells in $47(20.9 \%)$; Onodi cells in $44(19.6 \%)$; maxillary sinus hypoplasia in 6 (2.6\%); frontal sinus hypoplasia in 29
Table 1: The list of characteristics of paranasal sinus variations in paranasal CT.

\begin{tabular}{|c|c|}
\hline Gender & $122(54.2 \%)$ males, $103(45.8 \%)$ females \\
\hline Mean age & 28 years $(\min 15, \max .77)$ \\
\hline Nasal Septal & patients had deviation, $n=124(55.1 \%)$ \\
\hline Deviation & $\begin{array}{l}\text { right-sided deviation, } \mathrm{n}=84(37.3 \%) \\
\text { left-sided nasal deviation, } \mathrm{n}=40(17.8 \%)\end{array}$ \\
\hline \multirow[t]{2}{*}{$\begin{array}{l}\text { Nasal Turbinate } \\
\text { Variations }\end{array}$} & $\begin{array}{l}\text { Superior concha pneumatization, } n=30 \\
(13.3 \%)\end{array}$ \\
\hline & $\begin{array}{l}\text { Middle concha pneumatization, } n=100 \\
(44.4 \%)\end{array}$ \\
\hline Ethmoidal Cell & Agger nasi cells, $\mathrm{n}=192(85.3 \%)$ \\
\hline \multirow[t]{2}{*}{ Variations } & Haller cells, $n=47(20.9 \%)$ \\
\hline & Onodi cells, $n=44(19.6 \%)$ \\
\hline Hypoplasia/ & Maxillary sinus hypoplasia, $n=6(2.6 \%)$ \\
\hline Aplasia of & Frontal sinus hypoplasia, $n=29(12.9 \%)$ \\
\hline \multirow[t]{2}{*}{ Sinuses } & Frontal sinus aplasia, $\mathrm{n}=7(3.1 \%)$ \\
\hline & Sphenoid sinus hypoplasia, $n=7(3.1 \%)$ \\
\hline Accessory & Uncinate process pneumatization, $n=12$ \\
\hline \multirow[t]{3}{*}{ Pneumatization } & $(5.3 \%)$ \\
\hline & $\begin{array}{l}\text { Anterior clinoid process pneumatization, } \mathrm{n}=60 \\
(26.7 \%)\end{array}$ \\
\hline & $\begin{array}{l}\text { Pterygoid process pneumatization, } \mathrm{n}=75 \\
(33.3 \%)\end{array}$ \\
\hline Optic Nerve & Type $1, n=122(54.2 \%)$ \\
\hline \multirow[t]{3}{*}{ Classification } & Type $2, n=29(12.9 \%)$ \\
\hline & Type $3, n=36(16 \%)$ \\
\hline & Type 4, n=38 (16.9\%) \\
\hline Vidian Canal & Type $1, n=37(16.4 \%)$ \\
\hline \multirow[t]{2}{*}{ Classification } & Type $2, n=95(42.2 \%)$ \\
\hline & Type 3, n=93 (41.3\%) \\
\hline
\end{tabular}

(12.9\%); frontal sinus aplasia in 7 (3.1\%); sphenoid sinus hypoplasia in $7(3.1 \%)$; uncinate process pneumatization in $12(5.3 \%)$; ACP pneumatization in $60(26.7 \%)$ and PP pneumatization in 75 (33.3\%) patients. Optic nerve Type 1 was detected in 122 (54.2\%) patients, Type 2 in 29 (12.9\%), Type 3 in $36(16 \%)$ and Type 4 in $38(16.9 \%)$ patients. Vidian canal Type 1 was observed in 37 (16.4\%), Type 2 in 95 (42.2\%) and Type 3 in 93 (41.3\%) patients. (See Table 1) When we analyzed the impact of sex on other variables in our study, we ascertained that hypoplasia/aplasia of the sinuses was more prevalent in female patients $(\mathrm{p}=0.006)$. There was no effect of septal deviation on the other parameters of our study. There was a statistically significant positive association between the presence of ANC and Haller cells ( $\mathrm{p}=0.023) .47$ patients had Haller cells and 45 also had ANC. Hypoplasia/aplasia of the paranasal sinuses had a statistically significant negative association with 
the presence of ANC $(\mathrm{p}<0.001)$. There was also association between the presence of a type 3 Vidian canal and the absence of an ANC ( $p=0.051)$. Of the 33 patients who did not have ANC, 20 of them had type 3 Vidian canal. The association between a type 4 optic nerve and an Onodi cell was strongly statistically significant, as expected $(\mathrm{p}<0.001)$. The most prevalent Vidian canal was type 2, and it also had a statistically significant positive association with hypoplasia/aplasia of the sinuses $(\mathrm{p}=0.002)$. Furthermore, there was a statistically significant negative correlation between PP pneumatization and hypoplasia/aplasia of the sinuses $(\mathrm{p}=0.004)$. Of the 49 hypoplasia/aplasia patients, only 8 of them had PP pneumatization. ACP pneumatization had strong associations with the presence of PP pneumatization, different optic nerve types and Vidian canal types (Table 2, Table 3). Of the 60 cases with ACP pneumatization, 41 of them also had PP pneumatization (Table 4). The presence of ACP pneumatization was linked with the presence of a Type 3 optic nerve and Type 2 Vidian canal. Of the 122 optic nerve type 1 patients, only 13 of them had ACP pneumatization, and 29 of them had PP pneumatization. Of the 93 type 3 Vidian canal patients, only 10 of them had ACP pneumatization, and 6 of them had PP pneumatization. Also, presence of a Type 1 optic nerve was strongly linked to having a Type 3 Vidian canal $(\mathrm{p}<0.001)$.

Table 2: The association between optic nerve types and the presence of anterior clinoid process pneumatization on Paranasal CT.

\begin{tabular}{ccccc} 
& \multicolumn{3}{c}{ Anterior Clinoid Process } \\
pneumatization & & \\
& Present & Absent & Total & \\
Optic nerve \\
types
\end{tabular}

Table 3: The association between Vidian canal types and the presence of anterior clinoid process pneumatization on Paranasal CT

\begin{tabular}{|c|c|c|c|c|}
\hline \multirow[b]{3}{*}{$\begin{array}{l}\text { Vidian canal } \\
\text { types }\end{array}$} & \multicolumn{3}{|c|}{$\begin{array}{l}\text { Anterior Clinoid Process } \\
\text { Pneumatization }\end{array}$} & \multirow[b]{3}{*}{$P$ value } \\
\hline & Present & Absent & Total & \\
\hline & & & & \\
\hline \multirow[t]{2}{*}{1} & 18 & 19 & 37 & \\
\hline & $48.60 \%$ & $51.40 \%$ & $100.00 \%$ & \\
\hline \multirow[t]{2}{*}{2} & 32 & 63 & 95 & $p<0.001$ \\
\hline & $33.70 \%$ & $66.30 \%$ & $100.00 \%$ & \\
\hline \multirow[t]{2}{*}{3} & 10 & 83 & 93 & \\
\hline & $10.80 \%$ & $89.20 \%$ & $100.00 \%$ & \\
\hline \multirow[t]{2}{*}{ Total } & 60 & 165 & 225 & \\
\hline & $26.70 \%$ & $73.30 \%$ & $100.00 \%$ & \\
\hline
\end{tabular}

Table 4: The association between the presence of pterygoid process pneumatization and the presence of anterior clinoid process pneumatization on Paranasal CT.

\begin{tabular}{lllll} 
& \multicolumn{4}{c}{$\begin{array}{c}\text { Anterior Clinoid Process } \\
\text { Pneumatization }\end{array}$} \\
& Present & \multicolumn{1}{c}{ Absent } & Total & \\
$\begin{array}{l}\text { Pterygoid } \\
\text { process pneu- } \\
\text { matization }\end{array}$ & & & & P value \\
\hline Present & 41 & 34 & 75 & \\
& $54.70 \%$ & $45.30 \%$ & $100.00 \%$ & p $<0.001$ \\
Absent & 19 & 131 & 150 & \\
& $12.70 \%$ & $87.30 \%$ & $100.00 \%$ & \\
Total - & 60 & 165 & 225 & \\
& $26.70 \%$ & $73.30 \%$ & $100.00 \%$ & \\
\hline
\end{tabular}

\section{Discussion}

In this study, we examined the paranasal sinus CT variations in 225 patients scanned by MDCT. Our NSD rate was $55.1 \%$, and right-sided deviation was prominent. In a multicentre study by Mladina $e t$ al., the rate of NSD rate was $89.2 \%$, with a slight left-side dominance. In a Turkish study by Turna et al., the rate of NSD was $59.1 \%$, however in research published by Onwuchekwa et al., from Nigeria, the rate of NSD was only $20.91 \% .{ }^{[5]}$ Mladina et al. determined the incidence of NSD by anterior rhinoscopy, 
whereas paranasal sinus CT was used by Turna $e t$ al. and Onwuchekwa et al. ${ }^{[3,4,5]}$

The middle concha pneumatization rate was $44.4 \%$, and the superior concha pneumatization rate $13.3 \%$ in this study, where only bulbous type of middle turbinate pneumatization was included. In the study of Turna $e t a l .{ }^{[4]}$, the concha bullosa rate was $57.2 \%$, and the superior concha pneumatization rate $17.9 \%$. In the study by Onwuchekwa et al. ${ }^{[5]}$ the concha bullosa rate was $32.7 \%$, and the superior concha pneumatization rate was $6.3 \%$. In the study undertaken by Bolger et al., the concha bullosa rate was $53 \%$, and the paradoxical middle concha rate was $26.1 \%$. ${ }^{[6]}$

The rate of ANC was $85.3 \%$, Haller cells were found in $20.9 \%$ and Onodi cells were seen in $19.6 \%$ in this research. In the study by Bolger et al., the agger nasi cell rate was $98.5 \%$, the Haller cell rate was $45.1 \%$, and in Tonai et al.'s research, the agger nasi cell rate was $86.7 \%$, and the Haller cell rate was $36 \%$, in line with our findings ${ }^{[6,7]}$. The Onodi cell rate was $13.5 \%$ and $12 \%$ in the research undertaken by Turna et al. and Arslan et al., respectively ${ }^{[4,8]}$.

The most frequent paranasal sinus ventilation anomaly in our study was frontal sinus hypoplasia (12.5\%). In the research by Turna et al., the frontal sinus ventilation hypoplasia rate was $12.5 \%$, close to what we found, whilst the frontal sinus aplasia rate was $1.7 \%$, lower than the prevalence we report. In the study by Onwuchekwa $\mathrm{et}$ al., the frontal sinus hypoplasia rate was $3.6 \%$, demonstrating racial differences amongst paranasal sinus ventilation variations. ${ }^{[4,5]}$ The uncinate process pneumatization rate in our research was $5.3 \%$, the ACP pneumatization rate was $26.7 \%$, and the PP pneumatization rate was $33.3 \%$, all in accordance with what previous studies in the literature have claimed. ${ }^{[1-7]}$

We classified optic nerve type in the sphenoid sinus according to the classification system proposed by Delano et al. ${ }^{[1]}$ Optic nerve Type 1 (54.2\%) was the most frequent nerve type, followed by Type 4 (16.9\%). In the study by Delano et al., and one by Al-Tameemi et al., the type 1 optic nerve was the most prevalent type, followed by type $2^{[1,9]}$. In our study, there was a statistically significant association between optic nerve type and the presence of ACP pneumatization, PP pneumatization and vidian canal type. Type 1 optic nerve was especially linked to the absence of ACP pneumatization, whilst type 3 was linked to the presence of ACP pneumatization. This relationship was also remarked upon in the study by Al-Tameemi et al. ${ }^{[9]}$ Moreover, type 1 optic nerve was linked to the absence of PP pneumatization and the presence of type 3 vidian nerve.

The vidian canal within the sphenoid bone corpus was classified according to the scheme followed by Lee et al. [2] The most frequent vidian canal type was type $2(42.2 \%)$ followed by type 3 (41.3\%). In the study by Lee et al. the most prevalent type was type $2(47 \%)$, followed by type $1(28 \%)$. In our study, there was a statistically significant association between possession of a type 3 vidian canal and hypoplasia of the paranasal sinuses. Also, presence of a type 3 vidian canal was linked to the absence of ACP pneumatization or PP pneumatization. The type 1 vidian canal was correlated with the highest PP pneumatization rate. As our study is the first to compare vidian canal types with the presence of ACP and PP pneumatization, there are no results within the literature available for comparative purposes.

\section{Conclusion:}

The analysis of paranasal CT is crucial in the diagnosis of miscellaneous diseases of the paranasal sinuses and in preoperative assessment prior to functional endoscopic sinus surgery. Anatomical variations of the sinuses are highly prevalent, hence otolaryngologists should be aware of these variations to allow precise diagnoses to be reached and surgical complications avoided. 


\section{References}

1) DeLano MC, Fun F, Zinreich SJ. Relationship of the optic nerve to the posterior paranasal sinuses: a CT anatomic study. American journal of neuroradiology. 1996;17:669-675.

2) Lee J-C, Kao C-H, Hsu C-H, Lin Y-S. Endoscopic transsphenoidal vidian neurectomy. Eur Arch Otorhinolaryngol. 2011;268(6):851-6.

3) Mladina R, Cujić E, Subarić M, Vuković K. Nasal septal deformities in ear, nose, and throat patients: an international study. Am J Otolaryngol. 2008 Mar-Apr;29(2):75-82

4) Turna O, Aybar M, Karagoz Y, Tuzcu G. Anatomic Variations of the Paranasal Sinus Region: Evaluation with Multidetector CT. Istanbul Medical Journal. 2014;15(2):104-9. doi: 10.5152/imj.2013.74429.

5) Onwuchekwa RC, Alazi N. Computed tomography anatomy of the paranasal sinuses and anatomical variants of clinical relevants in Nigerian adults. Egyptian Journal of Ear, Nose, Throat and Allied Sciences. 2017;18(1):31-8.
6) Bolger WE, Parsons DS, Butzin CA. Paranasal sinus bony anatomic variations and mucosal abnormalities: CT analysis for endoscopic sinus surgery. The Laryngoscope. 1991;101(1):56-64.

7) Tonai A, Baba S. Anatomic variations of the bone in sinonasal CT. Acta Otolaryngol Suppl 1996;525:9-13.

8) Arslan H, Aydinlioglu A, Bozkurt M, et al. Anatomical variations of the paranasal sinuses: CT examination for endoscopic sinus surgery. Auris Nasus Larynx 1999;26:39-48.

9) Al-Tameemi H, Hassan H. The Anatomical relationship of Optic Nerve Canal to the Posterior Paranasal Sinuses On Computerized Tomography in Iraqi Patients. Journal

10) of Contemporary Medical Sciences [Online], Volume 4 Number 3

This is an open access article distributed under the terms of the Creative Commons Attribution-NonCommercial-NoDerivs 3.0 Unported (CC BY- NC-ND3.0) Licence (http://creativecommons.org/licenses/by-nc-nd/3.0/) which permits unrestricted noncommercial use, distribution, and reproduc- tion in any medium, provided the original work is properly cited.

Please cite this article as: Yazıcı D., Evaluation of Anatomical Variations on Paranasal Sinus CT. ENT Updates 2018;8(3): 175-179. 